\title{
Copper-dioxygen complexes: Functional models for proteins
}

\author{
Kenneth D. Karlin, ${ }^{*}$ Dong-Heon Lee, Honorio V. Obias and Kristi J. Humphreys \\ Department of Chemistry, Charles and 34th Streets, The Johns Hopkins University, \\ Baltimore, Maryland 21218, U. S. A.
}

\begin{abstract}
The complex [(TMPA)CuI $(\mathrm{RCN})]^{+}(\mathbf{1})(\mathrm{TMPA}=\operatorname{tris}[(2-$ pyridyl $)$ methyl]amine $)$ binds $\mathrm{O}_{2}$ forming [ $\left.\left.(\mathrm{TMPA}) \mathrm{Cu}\right\}_{2}\left(\mathrm{O}_{2}\right)\right]^{2+}(2)$, with trans- $\mu-1,2$ peroxo-coordination. Study of complexes with binucleating ligand analogues provide considerable insights and achievement of room-temperature solution stability. Binucleating ligands with tridentate bis[(2-pyridyl)ethyl]amine chelates give side-on $\mu-\eta^{2}: \eta^{2}-$ peroxo dicopper(II) complexes, likewise in a monooxygenase model system. (P)Fe$\mathrm{X}-\mathrm{Cu}(\mathrm{L})\left(\mathrm{P}=\right.$ porphyrinate or binucleating tethered porphyrin; $\left.\mathrm{X}=\mathrm{O}^{2-}, \mathrm{OH}^{-}\right)$ oxidized resting state models of the heme $a_{3}$ and $\mathrm{Cu}_{\mathrm{B}}$ site of cytochrome $c$ oxidase have been generated and characterized, and reduced $(\mathrm{P}) \mathrm{Fe} I \mathrm{II} / \mathrm{Cu}^{\mathrm{I}}$ compounds, for $\mathrm{O}_{2}$ reactivity studies, have been synthesized. A heme/non-heme diiron complex has been generated as a possible model for NO reductase.
\end{abstract}

\section{INTRODUCTION}

Copper containing proteins perform a diverse array of functions, all involving oxidation-reduction (i.e. 'redox') activity, since the types of ligands (e.g., histidine, tyrosine and cysteine) typically found in protein matrices facilitate, in particular, redox shuttling between reduced copper(I), and copper(II) oxidation states. Small 'blue' copper proteins carry out electron transfer reactions, for example as electron carriers in photosynthetic organisms. Other copper proteins effect redox reactions which involve atom transfer, such as those involving the processing of molecular oxygen (Table 1) (1-6) or nitrogen oxides (7).

TABLE 1. Main Classes of Copper Proteins involved in $\mathrm{O}_{2}$-Processing (* X-ray Structures available).

\begin{tabular}{|c|c|c|}
\hline PROTEIN & SOURCE & BIOLOGICAL FUNCTION \\
\hline \multicolumn{3}{|l|}{ Oxygen Carrier } \\
\hline Hemocyanin $(\mathrm{Hc})^{*}$ & Molluscs and Arthropods & $\mathrm{O}_{2}$-transport \\
\hline \multicolumn{3}{|l|}{ Copper Monoxygenases } \\
\hline Tyrosinase (Tyr) & Fungal, Mammal & Tyrosine oxygenation \\
\hline Dopamine $\beta$-hydroxylase $(\mathrm{D} \beta \mathrm{H})$ & Adrenal, Brain & Dopamine $\rightarrow$ Norepinephrine \\
\hline $\begin{array}{l}\text { Peptidylglycine } \alpha \text {-Amidating } \\
\text { Monooxygenase (PAM) }\end{array}$ & Pituitary, Heart & $\begin{array}{l}\text { Oxidative N-dealkylation, } \\
\text { Neuropeptide hormone biosyn. }\end{array}$ \\
\hline Methane Monooxygenase (MMO) & Methanogenic bacteria & Methane $\rightarrow$ Methanol \\
\hline Ammonia Monooxygenase & Bacteria & $\mathrm{NH}_{3} \rightarrow \mathrm{NH}_{2} \mathrm{OH}$ \\
\hline \multicolumn{3}{|l|}{ Copper Dioxygenases } \\
\hline Quercetinase & Fungal & Quercetin oxidative cleavage \\
\hline \multicolumn{3}{|l|}{ Copper Oxidases } \\
\hline Ascorbate Oxidase (AO)* & Plants & Oxidation of $l$-ascorbate \\
\hline Laccase & Tree, Fungal & Phenol and diamine oxidation \\
\hline Ceruloplasmin* & Human, Animal serum & Ferrioxidase activity? \\
\hline Amine oxidase* & Most animals & Elastin, Collagen formation \\
\hline Galactose oxidase* & Molds & Galactose oxidation \\
\hline Cytochrome $c$ Oxidase $(\mathrm{C} c \mathrm{O})^{*}$ & Mitochondria & Terminal oxidase (Proton pump) \\
\hline \multicolumn{3}{|l|}{ Other } \\
\hline Superoxide Dismutase (SOD)* & Red blood cells, Animals & $\mathrm{O}_{2}^{-}$detoxification \\
\hline
\end{tabular}

Hemocyanins are blood $\mathrm{O}_{2}$-transporting proteins $(3,4)$. The deoxy state possesses three-coordinate cuprous ions $\left(\mathrm{Cu}\right.$... Cu $=4.6 \AA$ ) which bind $\mathrm{O}_{2}$ to give a peroxo-dicopper(II) oxy form, with $\mathrm{Cu}$... $\mathrm{Cu}=3.6$ $\AA, \lambda_{\max }=345(\varepsilon \sim 20,000)$ and $v(\mathrm{O}-\mathrm{O}) \sim 750 \mathrm{~cm}^{-1}$ (resonance Raman). Monooxygenases $(4,5)$ effect reactions involving oxygen-atom insertion into $\mathrm{C}-\mathrm{H}$ bonds. Oxidases oxidize or dehydrogenate organic substrates, accompanied by $\mathrm{O}_{2}$-reduction to either hydrogen peroxide or water (4). Cytochrome $c$ 
oxidases are mitochondrial terminal oxidases involved in $\mathrm{O}_{2}$-reduction to water concomitant with energy transduction via proton pumping (8). Copper/zinc superoxide dismutase (SOD) is well characterized, and recent evidence suggests that a point mutation in the $S O D$ gene may cause a degenerative disease of motor neurons, the inherited form of amyotrophic lateral sclerosis $(A L S)(9)$.

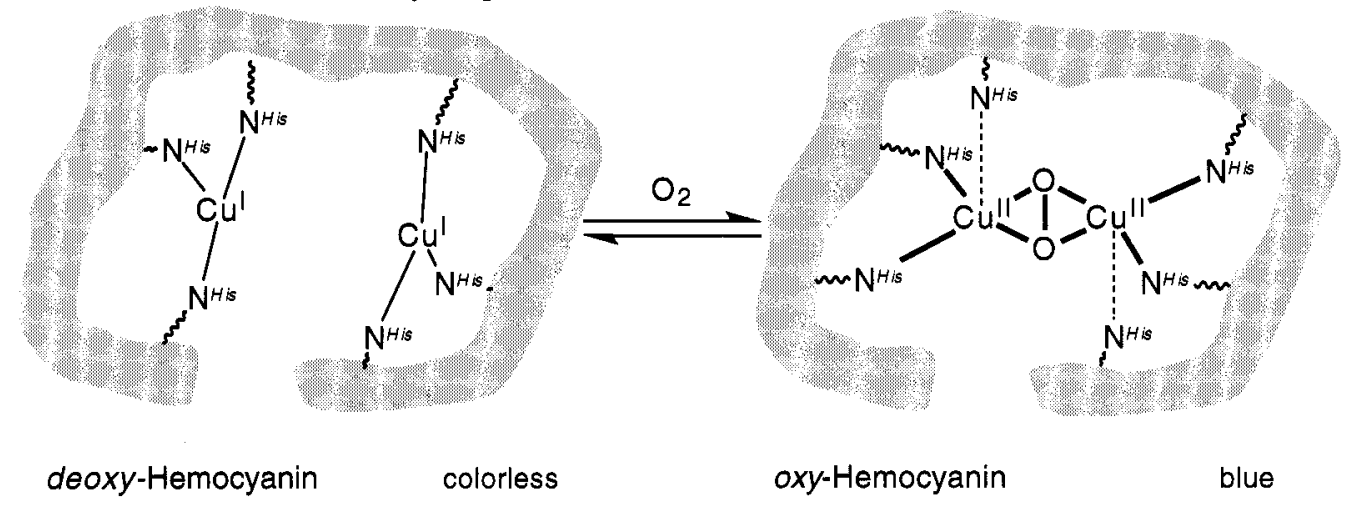

We, and others have endeavored to understand the structure and function of copper proteins involved in copper(I)/ $\mathrm{O}_{2}$ interactions, by studying inorganic models, i.e., synthetically derived copper(I) complexes, and their $\mathrm{O}_{2}$-reactivity $(2,3,6,10)$. Such biomimetic approaches can lead to fundamental insights into the metal-based chemistry, yielding an improved understanding of biological $\mathrm{O}_{2}$-activation mechanisms, and the dependence of reactivity patterns upon the specific nature of $\mathrm{Cu}_{\mathrm{n}}-\mathrm{O}_{2}$ structure. One might also envision the development of reagents or catalysts for use in practical oxidation processes. Here, we will highlight recent findings concerning the reversible binding of dioxygen to certain copper(I) complexes and $\mathrm{O}_{2}$-activation chemistry We also wish to describe chemistry related to the dinuclear iron-copper center in cytochrome $c$ oxidase $(\mathrm{CcO})$.

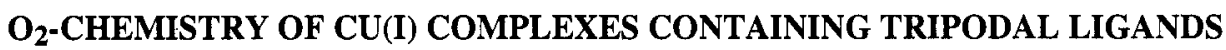

In order to model the neutral, aromatic, nitrogenous imidazolyl character observed in the histidyl-copper coordination found in hemocyanin and many other copper proteins, some of our studies have utilized synthetically accessible tripodal, tetradentate chelating pyridyl ligands, such as TMPA (TMPA = tris[(2pyridyl)methyl]amine). The first X-ray structurally characterized $\mathrm{Cu}_{2} \mathrm{O}_{2}$ species, the trans $-\mu-1,2$-peroxo $\left[\{(\mathrm{TMPA}) \mathrm{Cu}\}_{2}\left(\mathrm{O}_{2}\right)\right]^{2+}(\mathbf{2})$, was formed from the reaction of [(TMPA $\left.) \mathrm{Cu}(\mathrm{RCN})\right]^{+}(1)$ with $\mathrm{O}_{2}$ at $-80^{\circ} \mathrm{C}$ in EtCN or $\mathrm{CH}_{2} \mathrm{Cl}_{2}\left(\mathrm{Cu}: \mathrm{O}_{2}=2: 1\right.$, manometry). The $\mathrm{Cu}$ (II) ions in 2 are pentacoordinate, the $\mathrm{Cu}$-Cu distance is $4.359 \AA$ and the O-O bond length is $1.432 \AA(11 \mathrm{a})$. [ $\left.\{(\mathrm{TMPA}) \mathrm{Cu}\}_{2}\left(\mathrm{O}_{2}\right)\right]^{2+}(2)$ is intensely purple, displaying multiple strong $\mathrm{O}_{2}^{2-}$ to $\mathrm{Cu}$ (II) charge-transfer absorptions at $\lambda_{\max }=440 \mathrm{~nm}\left(\varepsilon=2000 \mathrm{M}^{-1} \mathrm{~cm}^{-}\right.$ 1), $525 \mathrm{~nm}(11500)$, and $590 \mathrm{~nm}(\mathrm{sh}, 7600)$. In addition, there is a d-d band at $1035 \mathrm{~nm}(180)$. Although $\mathrm{O}_{2}$ binds strongly to complex 1 at low temperatures, it can be removed reversibly by vacuum cycling experiments, i.e., application of vacuum while the solution is subjected to brief heating. Resonance Raman studies of 2 show an O-O stretch $\left(832 \mathrm{~cm}^{-1}\right)$ and a $\mathrm{Cu}-\mathrm{O}$ stretch $\left(561 \mathrm{~cm}^{-1}\right)(11 \mathrm{~b})$. Complex 2 also exhibits silent EPR and nearly normal ${ }^{1} \mathrm{H}$ NMR spectra. Magnetic susceptibility measurements performed on 2 indicate that $-2 J>600 \mathrm{~cm}^{-1}$, based on $\mathrm{H}=2 J \mathrm{~S}_{1} \cdot \mathrm{S}_{2}$. These results show that a single bridging $\mathrm{O}_{2}{ }^{2-}$ ligand can mediate strong magnetic coupling between two $\mathrm{Cu}$ (II) ions. Although 2 is a functional model for hemocyanin, it lacks the precise spectroscopic and structural signatures of the active site of oxyhemocyanin (vide supra), wherein $\eta^{2}: \eta^{2} \mathrm{O}_{2}^{2-}$ to dicopper(II) binding has been determined $(3,4)$. Kitajima and coworkers (3) have achieved the synthesis and structural/spectroscopic characterization of a model compound duplicating those properties observed in $o x y$-hemocyanin, using sterically hindered tridentate tris(pyrazolyl)borate ligands.

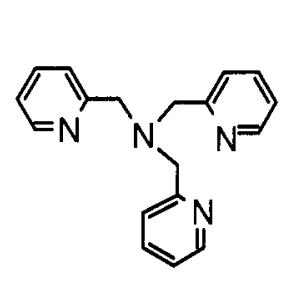

TMPA

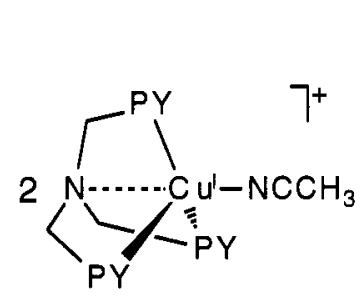

1

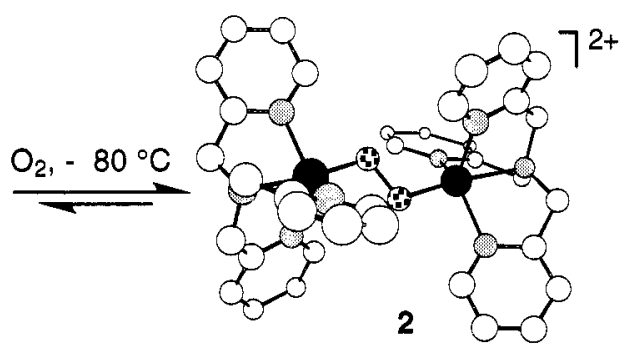




\section{Kinetic/Thermodynamics Investigations and Comparisons with Dinucleating Analogues.}

Kinetic/thermodynamic investigations carried out in collaboration with Professor A. D. Zuberbühler and co-workers in Basel, Switzerland, have revealed the formation of a primary $1: 1 \mathrm{Cu} / \mathrm{O}_{2}$ adduct in the reaction of $\mathrm{O}_{2}$ with $[(\mathrm{TMPA}) \mathrm{Cu}(\mathrm{RCN})]^{+}(\mathbf{1})$ and in a quinolyl analogue (6). $\left[(\mathrm{TMPA}) \mathrm{Cu}\left(\mathrm{O}_{2}\right)\right]^{+}\left(\mathbf{1}^{\prime}\right)$ forms as a spectroscopically observable $\left(\lambda_{\max }=410 \mathrm{~nm}\right)$ transient $\left(\mathrm{k}_{1}=1.8 \times 10^{4} \mathrm{M}^{-1} \mathrm{~s}^{-1}, \mathrm{~K}_{1}=1.9 \times 10^{3}\right.$ at $-90^{\circ} \mathrm{C} ; \Delta \mathrm{H}^{\circ}=-34 \mathrm{~kJ} / \mathrm{mol}, \Delta \mathrm{S}^{\circ}=-123 \mathrm{~J} / \mathrm{K}-\mathrm{mol}$ ); extrapolation to room temperature gives an $\mathrm{O}_{2}$ on-rate of $\sim 10^{8} \mathrm{M}^{-1} \mathrm{~S}^{-1}(6)$. This compares with or exceeds the $\mathrm{O}_{2}$-binding rate for heme proteins or iron-porphyrin complexes, many cobalt(II) chelates, and is comparable to the oxygenation rate of deoxy-hemocyanin.

More recently, we have synthesized dinucleating analogues, $\mathrm{D}^{1}$ and $\mathrm{DO}$, providing new insights and the ability to stabilize $\mathrm{Cu}_{2} \mathrm{O}_{2}$ adducts at room temperature in solution, a long elusive goal in the field. In EtCN solvent, the dicopper(I) complex $\left[\left(\mathrm{D}^{1}\right) \mathrm{Cu}_{2} \text { - }(\mathrm{EtCN})_{2}\right]^{2+}(3)$ proceeds to give an intramolecular peroxodicopper(II) product $\left[\left(\mathrm{D}^{1}\right) \mathrm{Cu}_{2} \mathrm{I}_{2}\left(\mathrm{O}_{2}^{2-}\right)\right]^{2+}\left(\mathbf{5}, \mathrm{L}=\mathrm{D}^{1}, \lambda_{\max }\right.$ $=540 \mathrm{~nm})$, analogous to [(TMPA)Cu $\}_{2^{-}}$ $\left.\left(\mathrm{O}_{2}\right)\right]^{2+}(2)$. However, a detailed analysis reveals that while $\mathrm{D}^{1}$ helps to overcome the entropic handicap inherent in formation of 2 , the $-\mathrm{CH}_{2} \mathrm{CH}_{2}$ - linker in $\mathrm{D}^{1}$ causes steric constraints making product 5 strained (6). Activation enthalpies for formation of 5 are 20 $\mathrm{kJ} \mathrm{mol}^{-1}$ higher for dioxygen binding $\left(\mathrm{k}_{2}, \mathrm{k}_{\text {on }}\right.$ $=\mathrm{k}_{1} \mathrm{k}_{2} / \mathrm{k}_{-1}$ ), but more than $20 \mathrm{~kJ} \mathrm{~mol}^{-1}$ lower for $\mathrm{Cu}-\mathrm{O}$ bond splitting $\left(\mathrm{k}_{-2}\right)$, as compared to 2. The net result is a massive loss in overall enthalpy of formation, $\Delta \mathrm{H}_{\mathrm{on}}{ }^{\circ}$, reduced to -35 $\mathrm{kJ} \mathrm{mol}^{-1}$ for $5\left(\mathrm{~L}=\mathrm{D}^{1}\right)$ compared to $-81 \mathrm{~kJ}$ $\mathrm{mol}^{-1}$ for 2. Ring closure (i.e., peroxo formation) itself $\left(\mathrm{K}_{2}\right)$ has a slightly endothermic reaction enthalpy, $0.5 \mathrm{~kJ} \mathrm{~mol}^{-1}$ (6). The strain in fact results in a rearrangement at higher temperatures $\left(>\sim-50^{\circ} \mathrm{C}\right)$,
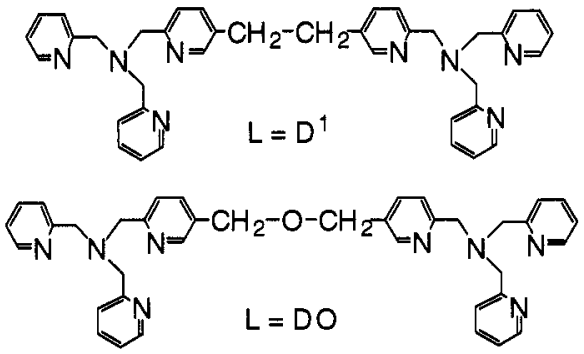

leading to the formation of a trimer, $\left[\left\{\left(\mathrm{D}^{1}\right) \mathrm{Cu}_{2} \mathrm{II}_{2}\left(\mathrm{O}_{2}{ }^{2-}\right)\right\}_{3}\right]^{6+}$, with intermolecular $\mu$-peroxo moieties.

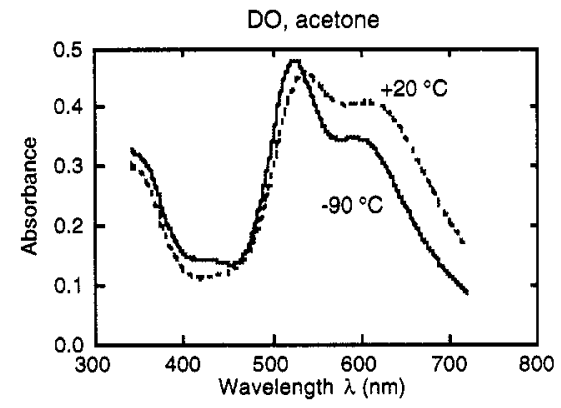

We find that acetone as a solvent (compared to EtCN) confers considerable room temperature stability to $5(\mathrm{~L}=$ $\left.D^{1}\right), K_{1} K_{2}>4 \times 10^{3} \mathrm{M}^{-1}$ and $t_{1 / 2}$ (decomp.) $\sim 40$ s. With $\mathrm{DO}$ as the dinucleating ligand, the longer more flexible $-\mathrm{CH}_{2} \mathrm{OCH}_{2}$ - linker apparently overcomes the steric constraints observed for the $\mathrm{D}^{1}$ complex. Surprisingly, we do not observe formation of $\mathrm{Cu} / \mathrm{O}_{2} 1: 1$ adducts such as 4 for $\mathrm{L}=\mathrm{DO} ;\left[(\mathrm{DO}) \mathrm{Cu}_{2} \mathrm{II}_{2}\left(\mathrm{O}_{2}{ }^{2-}\right)\right]^{2+}(\mathbf{5})$ is formed rapidly and with great stability, even at room temperature. $\left[(\mathrm{DO}) \mathrm{Cu}_{2}{ }_{2}\left(\mathrm{O}_{2}{ }^{2-}\right)\right]^{2+}(\mathbf{5}, \mathrm{L}=\mathrm{DO})$ fully forms at room temperature (as shown by the accompanying spectra at -90 ${ }^{\circ} \mathrm{C}$ compared to $+20^{\circ} \mathrm{C}$ ) with $t_{1 / 2}$ (decomp.) $\sim 60 \mathrm{~s} \mathrm{(12).}$

\section{O $_{2}$-BINDING/ACTIVATION WITH TRIDENTATE LIGAND COMPLEXES}

Another class of compounds we have studied use dinucleating ligands where two bis[2-(2pyridyl)ethyl]amine (PY2) units are linked through the amino nitrogens by a variable $-\left(\mathrm{CH}_{2}\right)_{\mathrm{n}^{-}}(\mathrm{n}=3-5)$ hydrocarbon spacer $(3,10,13)$. For tricoordinate complexes $\left[\mathrm{Cu}_{2}(\mathrm{Nn})\right]^{2+}(6)$ or tetracoordinate nitrile adducts $\left[\mathrm{Cu}_{2}(\mathrm{Nn})\left(\mathrm{CH}_{3} \mathrm{CN}\right)_{2}\right]^{2+}(\mathbf{6 a})$, reversible binding has been demonstrated. These react with $\mathrm{O}_{2}$ at $-80^{\circ} \mathrm{C}$ in $\mathrm{CH}_{2} \mathrm{Cl}_{2}$ solution, producing deep brown or purple species $\left[\mathrm{Cu}_{2}(\mathrm{Nn})\left(\mathrm{O}_{2}\right)\right]^{2+}(8)$. As found for our other copper dioxygen complexes, reversible $\mathrm{O}_{2}$ and $\mathrm{CO}$ binding can be followed 
spectrophotometrically. Carbon monoxide binding to 6 is stronger than $\mathrm{O}_{2}$, since $\mathrm{CO}$ can displace $\mathrm{O}_{2}$ from 8 to give $\left[\mathrm{Cu}_{2}(\mathrm{Nn})(\mathrm{CO})_{2}\right]^{2+}$ (7). The relative binding strength of $\mathrm{CO}$ vs. $\mathrm{O}_{2}$ to reduced copper ion parallels that observed for heme-proteins and porphyrin-iron(II) complexes.
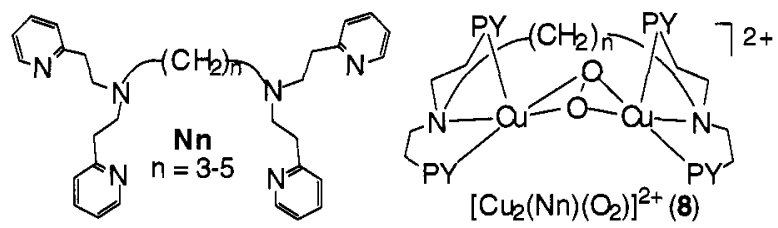

Complexes $\left[\mathrm{Cu}_{2}(\mathrm{Nn})\left(\mathrm{O}_{2}\right)\right]^{2+}(\mathbf{8})$ possess striking UV-VIS properties, in particular a characteristic $350-360$ $\mathrm{nm}$ band with $\varepsilon=16-21000 \mathrm{M}^{-1} \mathrm{~cm}^{-1}$. The strong 350-360 nm band is characteristic of $\mu-\eta^{2}: \eta^{2}$ side-on peroxo coordination as seen with Kitajima's complex and oxy-hemocyanin (3); recent resonance Raman measurements on complexes $\mathbf{8}$ confirm this supposition. The position and relative intensity of a variable 400-500 $\mathrm{nm}$ absorption varies systematically with $\mathrm{n}$, reflecting subtle changes in the mode of $\mathrm{O}_{2}$ binding or the geometry of the $\mathrm{Cu}_{2}-\left(\mathrm{O}_{2}\right)$ moiety. X-ray absorption measurements carried out on the $\mathrm{N} 3$ and $\mathrm{N} 4$ derivatives confirm the $\mathrm{Cu}(\mathrm{II})$ oxidation state (XANES, near-edge structure), while also allowing determination of $\mathrm{Cu} \cdots \mathrm{Cu}$ distances, which are 3.3 and $3.4 \AA$, respectively. Thus, the data are consistent with a bent 'butterfly' $\mu-\eta^{2}: \eta^{2}$-peroxo dicopper(II) structure for $\left[\mathrm{Cu}_{2}(\mathrm{Nn})\left(\mathrm{O}_{2}\right)\right]^{2+}(\mathbf{8})$, as shown; the distortions from planarity are seen to arise from constraints associated with the binucleating $\mathrm{Nn}$ ligand. As with oxy-hemocyanin, $\left[\mathrm{Cu}_{2}(\mathrm{Nn})\left(\mathrm{O}_{2}\right)\right]^{2+}(8)$ complexes are EPR silent and diamagnetic $(3,10,13)$.

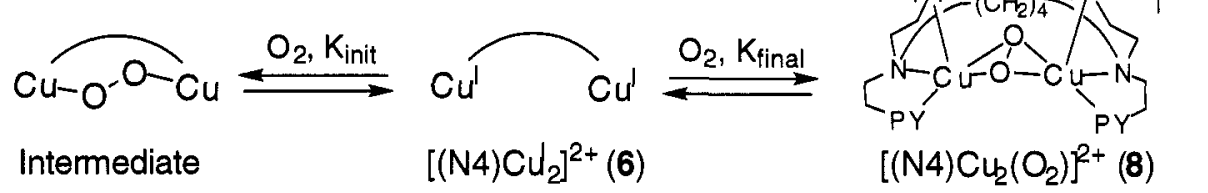

A recent insight into the dynamics associated with copper-dioxygen complex formation comes from a kinetic study of the formation of $\left[\mathrm{Cu}_{2}(\mathrm{~N} 4)\left(\mathrm{O}_{2}\right)\right]^{2+}(8)$ from oxygenation of the dicopper(I) complex, $\left[\mathrm{Cu}_{2}(\mathrm{~N} 4)\right]^{2+}(6)(6,14)$. A considerable binding strength is associated with $\mu-\eta^{2}: \eta^{2}$-peroxo formation in $\left[\mathrm{Cu}_{2}(\mathrm{~N} 4)\left(\mathrm{O}_{2}\right)\right]^{2+}\left(\Delta \mathrm{H}^{\circ}=-58 \mathrm{kJmol}^{-1}\right)$, which is compensated by a reaction entropy of $\Delta \mathrm{S}^{\circ}=-165 \mathrm{JK}^{-}$ ${ }^{1} \mathrm{~mol}^{-1}$. Most interestingly, at low temperatures, formation of this product is preceded by a less stable intermediate $\left(\Delta \mathrm{H}^{\circ}=-28 \mathrm{kJmol}^{-1}\right)$ whose spectral characteristics $\left(\lambda_{\max }=525 \mathrm{~nm}\right)$ implicate 'end-on' peroxo ligation. End-on to side-on peroxo conversion is likely to induce significant shortening of the $\mathrm{Cu}$... Cu distance from $\sim 4.4 \AA$ to $3.3-3.7 \AA$. Since $\mathrm{Cu}$...Cu $=4.6 \AA$ in deoxy-hemocyanin, but $3.6 \AA$ in oxy-hemocyanin, we suggest that an analogous thermodynamically driven rearrangement may be the basis for initiating subunit-subunit cooperativity in hemocyanin $\mathrm{O}_{2}$-binding $(6,14)$.

\section{A Monooxygenase Model System}

When the linker between PY2 moieties is a $m$-xylyl group (XYL-H), formation of a dicopper(I) complex 9 leads to dioxygen reactivity which closely resembles monooxygenase enzymes such as tyrosinase, with $\mathrm{C}$ -

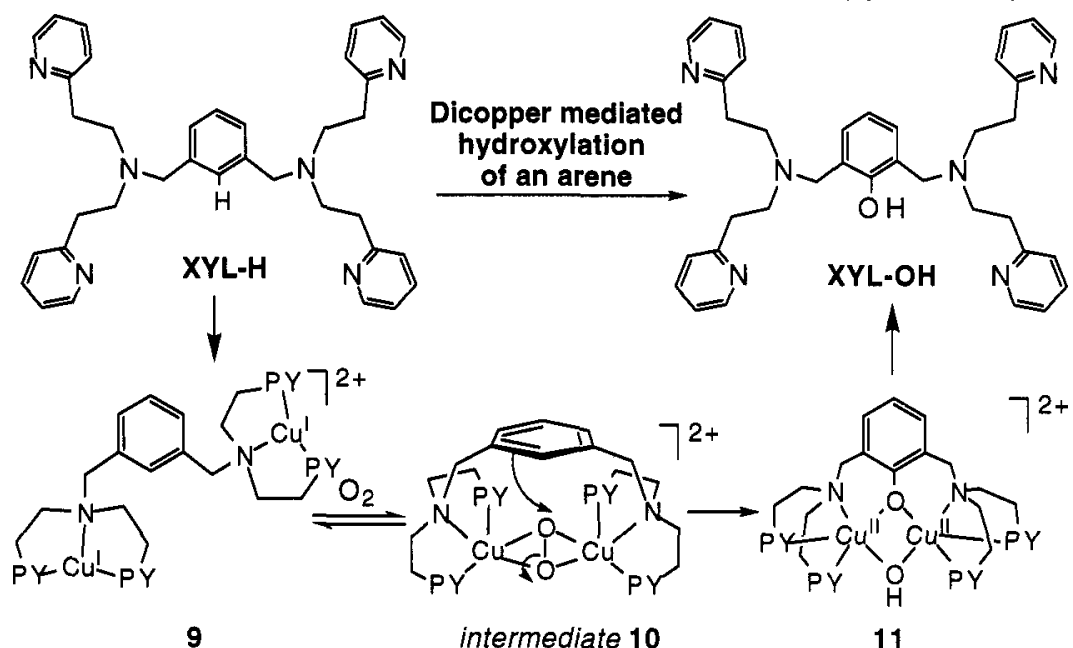

$\mathrm{H}$ activation incorporating one $\mathrm{O}$ atom from $\mathrm{O}_{2}$ into the ligand substrate. The product is the phenoxo and hydroxo-bridged dicopper(II) complex 11, from which the hydroxylated ligand $\mathrm{XYL}-\mathrm{OH}$ can be extracted, completing the dicopper mediated hydroxylation of an arene, under very mild conditions $\left(1 \mathrm{~atm} \mathrm{O}_{2}\right)$. Isotopic labeling experiments and the observed stoichiometry of reaction $\left(\mathrm{Cu} / \mathrm{O}_{2}=2: 1\right)$ are that expected of a monooxygenase. Detailed

mechanistic studies reveal that a $\mathrm{Cu}_{2}-\mathrm{O}_{2}$ intermediate 10 forms (reversibly) upon reaction of 9 with $\mathrm{O}_{2}$. The side-on $\mu-\eta^{2}: \eta^{2}$-peroxo structure (shown) for $\mathbf{1 0}$ is inferred by spectroscopic analogy to $\left[\mathrm{Cu}_{2}(\mathrm{~N} 4)\left(\mathrm{O}_{2}\right)\right]^{2+}(8)$ and from recent resonance Raman studies on a derivative in which the intermediate 
10 is stabilized at low temperatures by the presence of an electron withdrawing $-\mathrm{NO}_{2}$ group para to the xylyl ring position which becomes hydroxylated. Thus, as in the enzyme active site, the peroxo group in 10 is located in highly favorable proximity to the xylyl ligand substrate, and facile hydroxylation occurs by electrophilic attack on the arene substrate $\pi$ system. An "NIH shift" mechanism is involved, like that previously established for iron hydroxylases $(6,10,15)$.

\section{MODELS FOR THE Fe-Cu DINUCLEAR SITE IN CYTOCHROME $c$ OXIDASE}

Cytochrome $c$ oxidase $(\mathrm{CcO})$ is a terminal respiratory protein which catalyzes the four-electron fourproton reduction of $\mathrm{O}_{2}$ to water. The process is coupled to proton translocation across the cell membrane. The electrochemical potential gradient generated by this proton pumping process is ultimately used in the

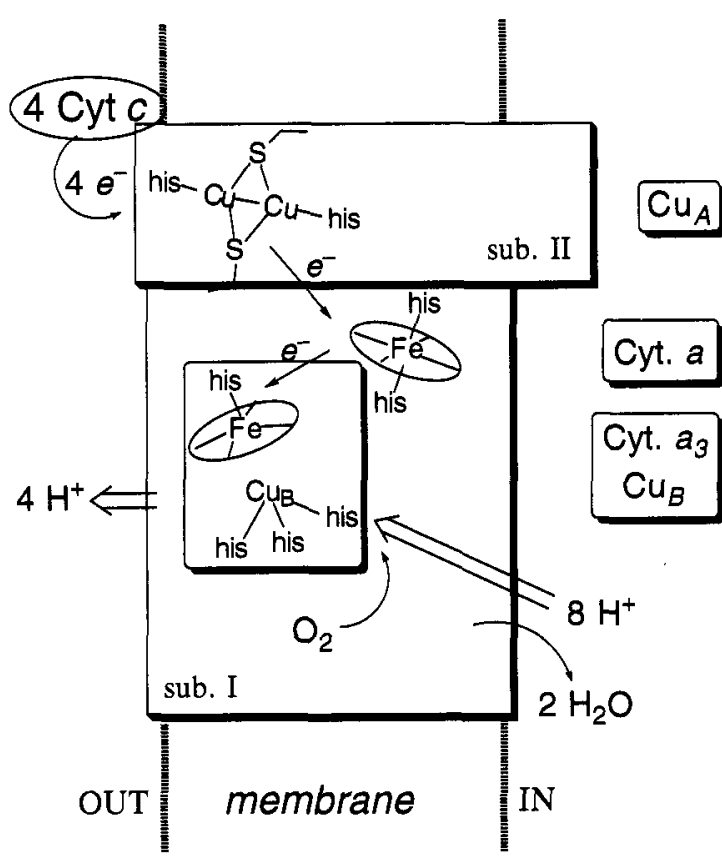
synthesis of ATP (8). Electrons are transferred to a binuclear cysteine-bridged mixed-valent dicopper $\left(\mathrm{Cu}_{\mathrm{A}}\right)$ center in subunit II. A low-spin heme $\mathrm{a}_{3}$ is also involved in electron transfer, but the critical $\mathrm{O}_{2}$-reduction site is the binuclear metal site consisting of a high-spin heme $a_{3}$ and closely neighboring $\mathrm{Cu}_{\mathrm{B}}-\left(\mathrm{N}_{\text {histidine }}\right)_{3}$ moiety. Recent enzyme $x$-ray crystal structures are available (8).

Considerable biochemical and inorganic modeling research efforts have focused on aspects of the 'asisolated' resting oxidized state of the dinuclear center, which may possess a spin-coupled $(-J>50$ $\left.\mathrm{cm}^{-1}\right) \mathrm{Fe}$ III-X-Cu II center. With our experience with copper(I)/O$/ \mathrm{O}_{2}$ chemistry, we have also been very interested in functional modeling $(2,10)$ of $\mathrm{CcO}$, i.e. $\mathrm{O}_{2}$-reaction chemistry involving reduced metals, with copper(I) and porphyrin-iron(II) species. For the enzyme, kinetic and spectroscopic evidence point to $\mathrm{Cu}_{\mathrm{B}}$ as the initial binding site for $\mathrm{O}_{2}$, thus highlighting the importance of $\mathrm{Cu}(\mathrm{I})-\mathrm{O}_{2}$ reactivity in the $\mathrm{O}_{2}$ reduction process of $\mathrm{CcO}(8)$. It is known that the $\mathrm{O}_{2}$-ligand transfers to the heme $\mathrm{a}_{3}$ forming an adduct analogous to that seen in hemoglobin.

Following this and injection of further reducing equivalents, the bound $\mathrm{O}_{2}$ is rapidly converted to other intermediates including an $\mathrm{O}-\mathrm{O}$ cleaved spectroscopically detectable ferryl $\mathrm{Fe}^{\mathrm{IV}}$-oxo species. The resting oxidized state is regenerated after the fourth electron transfer and protonation to give water (8).

\section{Synthesis and Characterization of Oxo/Hydroxo Bridged Iron-Copper Dinuclear Complexes}

In our initial attempts to delve into this type of chemistry, we chose to use TMPA-Cu complexes, since the $\mathrm{O}_{2}$-reactivity of [(TMPA) $\mathrm{Cu}^{\mathrm{I}}$ $\left.-\left(\mathrm{CH}_{3} \mathrm{CN}\right)\right]^{+}(\mathbf{1})$ is most understood. When an equimolar mixture of $\left(\mathrm{F}_{8}\right.$ $\mathrm{TPP}) \mathrm{Fe}^{\Pi I}$ (or an analogue with axial piperidine ligands) and 1 is reacted in the presence of dioxygen, $\left[\left(\mathrm{F}_{8}-\right.\right.$ TPP) $\mathrm{Fe}^{\text {III- }}-\left(\mathrm{O}^{2-}\right)-\mathrm{Cu}_{-}{ }_{-}$(TMPA) $]^{+}(\mathbf{1 2})$ is isolated. The same complex, identified by its UV-Vis and NMR spectroscopic + properties, can also be generated via an acid-base self-assembly reaction, by

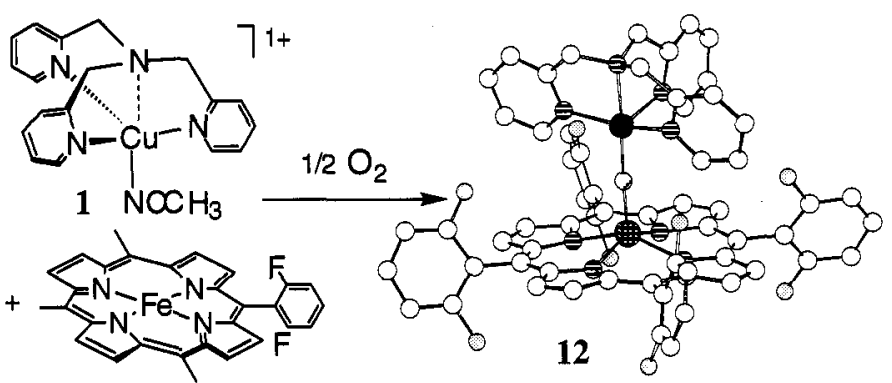

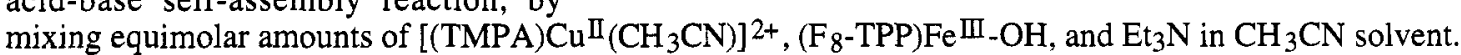

The structure of $\left[\left(\mathrm{F}_{8}-\mathrm{TPP}\right) \mathrm{Fe}^{\mathrm{III}}-\left(\mathrm{O}^{2-}\right)-\mathrm{Cu} \mathrm{I}_{(\mathrm{TMPA})]^{+}}(\mathbf{1 2})\right.$ reveals a linear $\mathrm{Fe}(\mathrm{III})$-oxo-Cu(II) coordination $\left(\angle \mathrm{Fe}-\mathrm{O}-\mathrm{Cu}=178.2^{\circ}\right)$, with short $\mathrm{Fe}-\mathrm{O}(1.740 \AA$, similar to $\mu$-oxo bridged iron-porphyrin dimers $)$ and $\mathrm{Cu}$ $\mathrm{O}(1.856 \AA)$ bond lengths. Physical measurements indicate 12 is an $\mathrm{S}=2$ spin system, with high-spin iron(III) strongly antiferromagnetically coupled $\left(J=-87 \mathrm{~cm}^{-1}\right.$ (solid), where $\left.H=-2 J \mathbf{S}_{1} \cdot \mathbf{S}_{2}\right)$ to an $\mathrm{S}=1 / 2$ $\mathrm{Cu}$ (II) ion center (16). This magnetic behavior gives rise to unusual ${ }^{1} \mathrm{H}-\mathrm{NMR}$ spectroscopic properties, 
with resonances at room temperature ranging from $+65 \mathrm{ppm}$ downfield to $-104 \mathrm{ppm}$ (upfield). The spectrum has been fully assigned and the NMR and electronic properties of $\mathbf{1 2}$ and its protonated analogue (vide infra) discussed in terms of current theory (17).

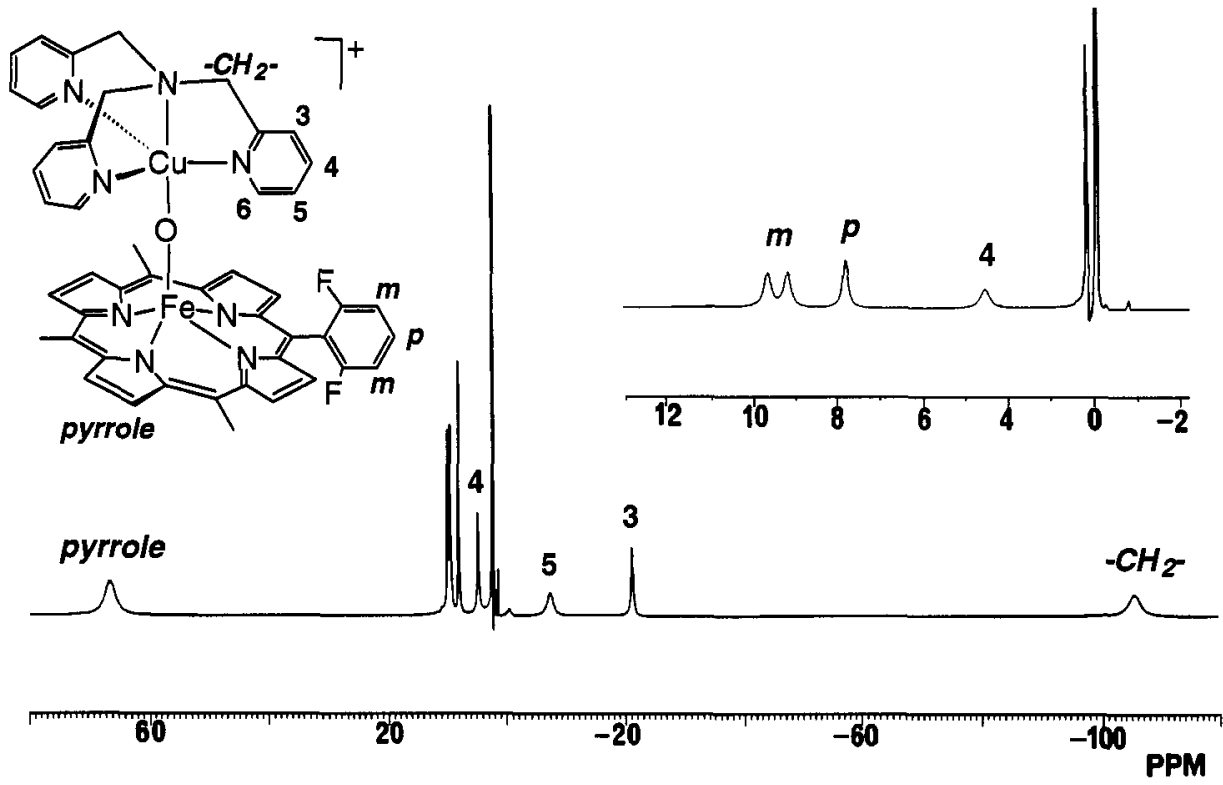

Protonation of $\left[\left(\mathrm{F}_{8}-\mathrm{TPP}\right) \mathrm{Fe}{ }_{-}-\left(\mathrm{O}^{2-}\right)-\mathrm{Cu} \mathrm{II}_{(\mathrm{TMPA})}\right]^{+}(\mathbf{1 2})$ by addition of one equivalent of $\mathrm{H}^{+}$produces the hydroxo-bridged complex, $\left[\left(\mathrm{F}_{8}-\mathrm{TPP}\right) \mathrm{Fe}-(\mathrm{OH})-\mathrm{Cu}(\mathrm{TMPA})\right]^{2+}(\mathbf{1 3})$. This can also be isolated by reacting an equimolar mixture of [(TMPA) $\left.\mathrm{Cu}^{\mathbb{I}}\left(\mathrm{CH}_{3} \mathrm{CN}\right)\right]^{2+}$ and $\left[\left(\mathrm{F}_{8}-\mathrm{TPP}\right) \mathrm{Fe}-\mathrm{OH}\right]$. Extended X-ray Absorption Fine Structure spectroscopy (EXAFS) measurements indicate 13 possesses elongated $\mathrm{Fe}-\mathrm{OH}$ and $\mathrm{Cu}-\mathrm{OH}$

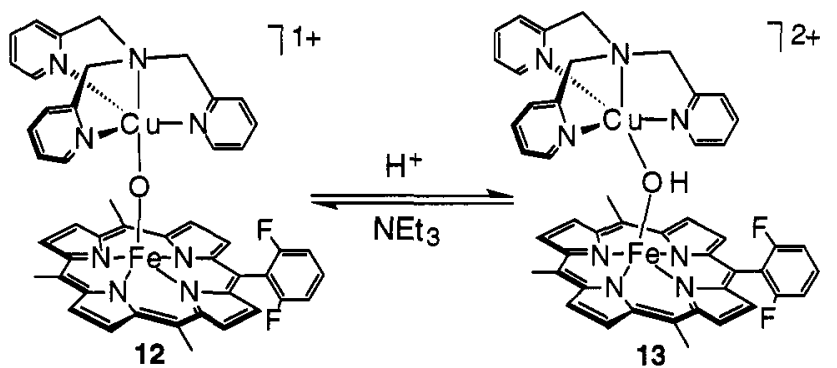
bonds and a bending such that $\angle \mathrm{Fe}-\mathrm{O}-\mathrm{Cu} \cong$ $2+157^{\circ}(18)$. This results in a loss of the outer shell strong multiple scattering observed in 12, due to its linear $\mathrm{Fe}-\mathrm{O}-\mathrm{Cu}$ moiety. We have suggested (18) that $\mathbf{1 3}$ is a plausible model for the resting ('as-isolated) oxidized enzyme, with its supposed $\mathrm{Fe}-\mathrm{X}-\mathrm{Cu}$ antiferromagnetic coupling. Since protonation of enzyme turnover intermediates leads to product water and/or translocated protons, it is of interest that the oxo moiety in 12 is basic; we estimate that $14<\mathrm{pK}_{\mathrm{a}}<17$ in $\mathrm{CH}_{3} \mathrm{CN}\left(\mathrm{pK}_{\mathrm{a}} \sim 8 \pm 2.5\right.$ in water) (18).

Isotopic labeling of the dioxygen reacted with $\left(\mathrm{F}_{8}-\mathrm{TPP}\right) \mathrm{Fe}^{\mathrm{II}}$ and $\mathbf{1}$ to give $\mathbf{1 2}$ indicates that the oxo group in the product is derived from $\mathrm{O}_{2}$, as judged by a new isotope sensitive IR band at $856 \mathrm{~cm}^{-1}$. Manometry reveals an $\mathrm{Fe} / \mathrm{Cu} / \mathrm{O}_{2}=2: 2: 1$ stoichiometry. Thus, our reaction system represents a crude functional model for $\mathrm{CcO}$. While the mechanism of reaction of this $\mathrm{Fe} / \mathrm{Cu} \mathrm{O}-\mathrm{O}$ bond cleavage reaction is of interest, we have instead chosen to turn our focus of structural, reactivity and mechanistic studies to the use of analogous systems involving binucleating ligands, such as ${ }^{5} \mathrm{~L}$ and ${ }^{6} \mathrm{~L}$, where $\mathrm{Ar}=2,6-$ difluorophenyl (19).

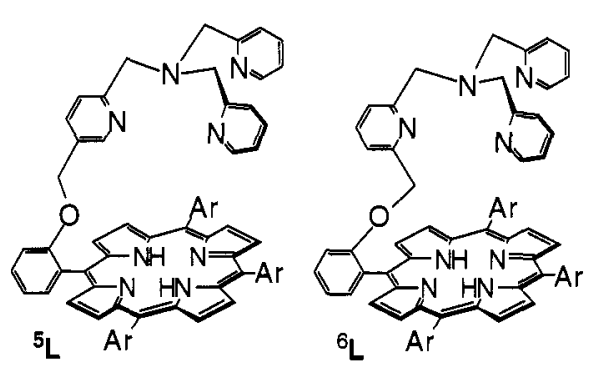

\section{Chemistry of Binucleating Ligands with TMPA Tethered to Porphyrins}

Introduction of ferric chloride to the binucleating ligand, ${ }^{5} \mathrm{~L}$, leads to the isolation of $\left[\left({ }^{5} \mathrm{~L}\right) \mathrm{Fe}-\mathrm{O}-\mathrm{Fe}(\mathrm{Cl})\right]^{+}$ (14), containing both heme and non-heme iron(III) bridged by an oxide atom (20). Complex $\mathbf{1 4}$ is characterized by UV-Vis bands at 411 (Soret) and $564 \mathrm{~nm}$. Mössbauer spectroscopy reveals distinctive 
$\mathrm{Fe}(\mathrm{III})$ sites, both being high-spin. ${ }^{1} \mathrm{H}-\mathrm{NMR}$ resonances in the $0-30 \mathrm{ppm}$ range and magnetic properties (3.4 $\mu_{\mathrm{B}} / \mathrm{Fe}$ at room-temperature) are consistent with the presence of antiferromagnetic coupling through the oxo-bridge in 14. An IR band at $835 \mathrm{~cm}^{-1}$ is assigned to an $\mathrm{Fe}-\mathrm{O}-\mathrm{Fe}$ asymmetric stretch; this shifts to $801 \mathrm{~cm}^{-1}$ upon treatment of the compound with $\mathrm{H}_{2}{ }^{18} \mathrm{O}$. The X-ray structure reveals short $\mathrm{Fe}-\mathrm{O}$ bonds; $\mathrm{Fe} . . . \mathrm{Fe}^{\prime}=3.484 \AA$, $\angle \mathrm{Fe}-\mathrm{O}-\mathrm{Fe}=157.3^{\circ}$. The bending is not seen as being caused by ligand constraints since a close analogue without tethered porphyrin binucleating ligand and which can be generated by acidbase self-assembly, $\left[\left(\mathrm{F}_{8}-\mathrm{TPP}\right) \mathrm{Fe}-\mathrm{O}-\mathrm{Fe}(\mathrm{TMPA})(\mathrm{Cl})\right]^{2+}\left(\mathbf{1 4}^{\prime}\right)$ possesses a very similar structure $(20)$.

Heme/non-heme complexes 14 and 14' may have biological relevance, since denitrifying bacterial nitric oxide reductases are evolutionarily related to heme-copper oxidases and possess a heme center with additional non-heme iron atom (21). Thus, this postulated binuclear center may comprise the catalytic core responsible for the reductive coupling of $2 \mathrm{NO}$ giving $\mathrm{N}_{2} \mathrm{O}$ and an oxo species like 14. Preliminary experiments suggest we may be able mimic this kind of behavior. Treatment of 14 with dithionite gives a reduced di-iron(II) species (in situ), which upon exposure to $\mathrm{NO}_{(\mathrm{g})}$ gives back 14. Detection of $\mathrm{N}_{2} \mathrm{O}$ is also suggestive; further experimentation and characterization is needed.

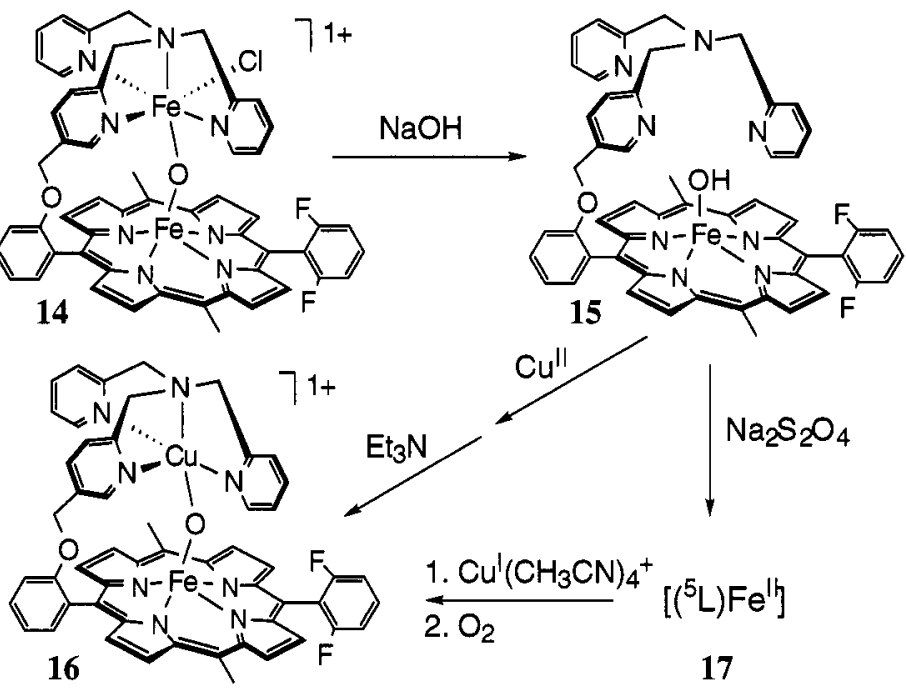

The ligand ${ }^{5} \mathrm{~L}$ also allows generation of complexes of interest for modeling $\mathrm{Cc} \mathrm{O}$. 'Rusting' out of the nonheme iron ion from 14 gives a high-spin Fe ${ }^{I I I}-\mathrm{OH}$ complex, $\left[\left({ }^{5} \mathrm{~L}\right) \mathrm{Fe}-\mathrm{OH}\right](\mathbf{1 5})$, with an empty tether. Addition of a copper(II) salt and base gives [( $\left.\left.{ }^{5} \mathrm{~L}\right) \mathrm{Fe}-\mathrm{O}-\mathrm{Cu}\right]+(16)$ as judged by its $\mathrm{UV}-\mathrm{Vis}$ and ${ }^{1} \mathrm{H}-\mathrm{NMR}$ properties, which parallel those of $\left[\left(\mathrm{F}_{8}-\mathrm{TPP}\right) \mathrm{Fe}^{\mathrm{II}}-\left(\mathrm{O}^{2-}\right)-\mathrm{Cu} \mathrm{I}(\mathrm{TMPA})\right]^{+}(\mathbf{1 2})$. Reduction of 15 gives an iron(II) species, 17, to which addition of copper(I) and $\mathrm{O}_{2}$ also gives 16 . The characterization and reactivity studies of a reduced $\mathrm{Fe}-\mathrm{Cu}$ complex such as $\left[\left({ }^{5} \mathrm{~L}\right) \mathrm{Fe} . . . \mathrm{Cu}\right]^{+}$are currently being pursued.

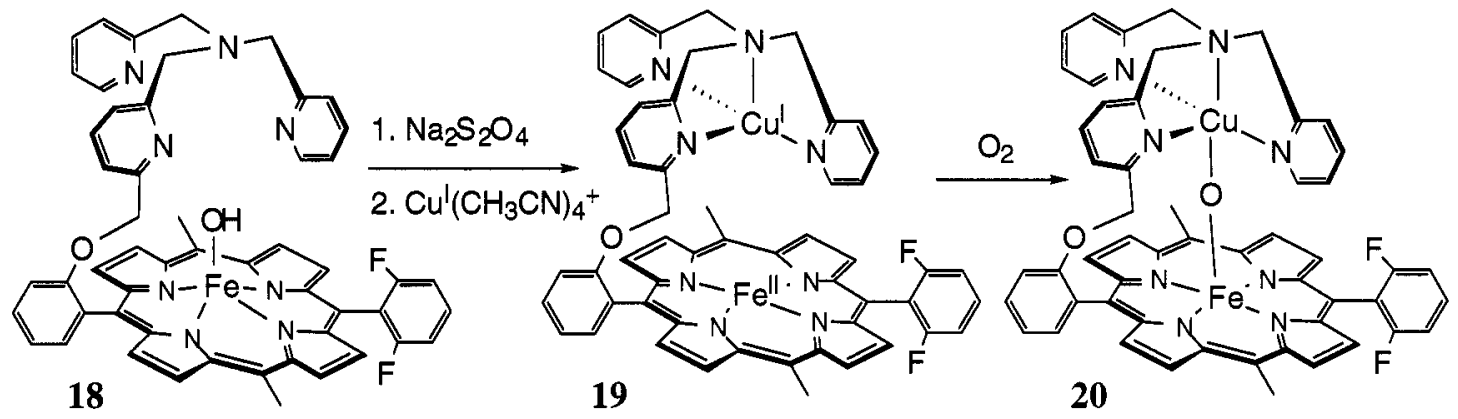

Similar chemistry can be achieved with the ${ }^{6} \mathrm{~L}$ binucleating ligand. An iron(III) complex with an empty TMPA tether analogous to 15 can be isolated, i.e., $\left[\left({ }^{6} \mathrm{~L}\right) \mathrm{Fe}-\mathrm{OH}\right](\mathbf{1 8})$. Reduction of this with dithionite and addition of a copper(I) salt afford 19; this is a reduced iron (II)-copper(I) complex, with $\lambda_{\max }=424$ $\mathrm{nm}$, and with NMR properties consistent with high-spin Fe(II) (tetrahydrofuran (THF) solvent). Reaction with $\mathrm{O}_{2}$ affords the $\mathrm{Fe}(\mathrm{III})-\mathrm{O}-\mathrm{Cu}(\mathrm{II})$ complex, $\left[\left({ }^{6} \mathrm{~L}\right) \mathrm{Fe}-\mathrm{O}-\mathrm{Cu}\right]^{+}(\mathbf{2 0})$, as judged by UV-Vis, ${ }^{1} \mathrm{H}$ NMR and $\mathrm{X}$-ray structural properties. EXAFS and X-ray structural studies also reveal significant structural differences in the $\mathrm{Fe}$-oxo-Cu complexes $\mathbf{1 6}$ and $\mathbf{2 0}$, undoubtedly caused by the differences in ligand contraints imposed by the ligands ${ }^{5} \mathrm{~L}$ versus ${ }^{6} \mathrm{~L}$. Another exciting preliminary observation is that when we carry out the oxygenation of 19 at $-80^{\circ} \mathrm{C}$ in THF solvent. a new spectroscopically distinct species is observed. This bodes well for future investigations where we wish to probe the possibility of forming $\mathrm{Fe}$ peroxo- $\mathrm{Cu}$ or other interesting intermediates which may have relevance to the processes of $\mathrm{O}_{2}$-binding, reduction, $\mathrm{O}-\mathrm{O}$ cleavage and proton translocation by the $\mathrm{Fe}-\mathrm{Cu}$ center in cytochrome $c$ oxidases. 


\section{SUMMARY/CONCLUSION}

Copper proteins involved in dioxygen binding or activation possess a variety of active site structures and chemistry. Such observations have led us to utilize a variety of ligands to develop model compounds and reaction chemistry which can provide information about fundamental aspects of copper complex interactions and reactions with $\mathrm{O}_{2}$. [(TMPA $\left.) \mathrm{Cu}^{\mathrm{I}}(\mathrm{RCN})\right]^{+}(\mathbf{1})$ binds $\mathrm{O}_{2}$ reversibly at $-80^{\circ} \mathrm{C}$ to give the $\mathrm{Cu} / \mathrm{O}_{2}=2: 1\left(\mathrm{Cu}: \mathrm{O}_{2}\right)$ trans- $\mu-1,2-$ peroxo adduct $\left[\{(\mathrm{TMPA}) \mathrm{Cu}\}_{2}\left(\mathrm{O}_{2}\right)\right]^{2+}(2)$. This structure is not that found in the biological $\mathrm{O}_{2}$-carrier protein hemocyanin, but this and other studies indicate that biomimetic reversible $\mathrm{O}_{2}$-binding in synthetic copper complexes can be studied, and that a number of $\mathrm{Cu}_{\mathrm{n}}-\mathrm{O}_{2}$ binding modes are possible. The binucleating analogues, $\mathrm{D}^{1}$ and $\mathrm{DO}$, provide insights about the relative stabilities of peroxo-dicopper(II) complexes, intra vs. inter-molecular copper-dioxygen binding, and how ligand design can lead to $\mathrm{Cu}_{2}-\mathrm{O}_{2}$ complexes which are stable at room temperature in solution. Binucleating ligands with two connected bis[2-(2-pyridyl)ethyl]amine (PY2) units lead to dicopper(I) complexes which also reversibly bind $\mathrm{O}_{2}$ (and $\mathrm{CO}$ ), and which have the $\mu-\eta^{2}: \eta^{2}$ side-on peroxo coordination seen in oxyhemocyanin. Small changes in the ligand, i.e. the nature of the linker between PY2 moieties, causes spectroscopic and structural changes in the $\mathrm{Cu}_{2}-\mathrm{O}_{2}$ moiety. When the linker is a $m$-xylyl moiety, a model system for copper monooxygenation has been characterized, since oxygenation of the dicopper(I) in that system (XYL ligand) results in the facile and regiospecific hydroxylation of the xylyl ring. Mechanistic studies implicate a $\mu-\eta^{2}: \eta^{2}$-peroxo intermediate which attacks the substrate in an electrophilic reaction. Our attention in the last few years has also turned to studies aimed at modeling the $\mathrm{Fe}$-Cu binuclear center of cytochrome $c$ oxidases. An initial biomimetic reaction utilizes $1,\left(\mathrm{~F}_{8}-\mathrm{TPP}\right) \mathrm{Fe}$ II and $\mathrm{O}_{2}$, which produces

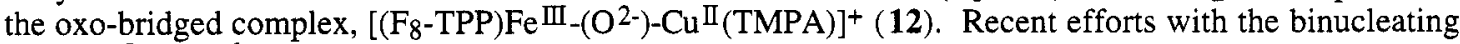
ligands, ${ }^{5} \mathrm{~L}$ and ${ }^{6} \mathrm{~L}$, having a TMPA moiety tethered to a porphyrin periphery are leading to exciting new chemistry, including the heme/non-heme diiron complex, $\left[\left({ }^{5} \mathrm{~L}\right) \mathrm{Fe}-\mathrm{O}-\mathrm{Fe}(\mathrm{Cl})\right]^{+}(\mathbf{1 4})$, as a model for NO reductase, $\mathrm{Fe}-\mathrm{Cu}$ complexes analogous to 12 , and the ability to produce reduced $\mathrm{Fe}$ (II)- $\mathrm{Fe}$ (II) and $\mathrm{Fe}$ (II)$\mathrm{Cu}(\mathrm{I})$ complexes for future reactivity investigations.

\section{REFERENCES}

(1) K.D. Karlin and Z. Tyeklár, Eds., Bioinorganic Chemistry of Copper, Chapman \& Hall, NY (1993).

(2) K.D. Karlin, Science, 261, 701-708 (1993).

(3) N. Kitajima and Y. Moro-oka, Chem. Rev. 94, 737 (1994).

(4) E.I. Solomon, U. M. Sundaram and T. E. Machonkin, Chem. Rev., 96, 2563-2605 (1996).

(5) J. P. Klinman, Chem. Rev., 96, 2541-2561 (1996).

(6) K.D. Karlin, S. Kaderli and A.D. Zuberbühler, Acc. Chem. Res., 30, 139-147 (1997).

(7) B.A. Averill, Chem. Rev., 96, 2951-2964 (1996). W.G. Zumft and P.M.H. Kroneck, Adv. Inorg. Biochem., 11, 193-221 (1996).

(8) S. Ferguson-Miller and G. T. Babcock, Chem. Rev., 96, 2889-2907 (1996) and refs. cited therein.

(9) I. Fridovich, Annu. Rev. Biochem., 64, 97-112 (1995).

(10) (a) K.D. Karlin, Z. Tyeklár, and A.D. Zuberbühler, Bioinorganic Catalysis, 261, Marcel Dekker, NY (1992). (b) K. D. Karlin and Z. Tyeklár, Adv. Inorg. Biochem., 9, 123-172 (1994).

(11) (a) Z. Tyeklár, R. R. Jacobson, N. Wei, N. Narasimha Murthy, J. Zubieta and K. D. Karlin, J. Am. Chem. Soc. 115, 2677-2689 (1993). (b) M.J. Baldwin, P.K. Ross, J.E. Pate, Z. Tyeklár, K.D. Karlin, and E.I. Solomon, J. Am. Chem. Soc. 113, 8671-8679 (1991).

(12) K.D. Karlin, D.-H. Lee, S. Kaderli and A. D. Zuberbühler, Chem. Commun., 475-476 (1997).

(13) K. D. Karlin, Z. Tyeklár, A. Farooq, M. S. Haka, P. Ghosh, R. W. Cruse, Y. Gultneh, J. C. Hayes, P. J. Toscano and J. Zubieta, Inorg. Chem., 31, 1436-1451 (1992).

(14) B. Jung, K.D. Karlin and A. D. Zuberbühler, J. Am. Chem. Soc. 118, 3763-3764 (1996).

(15) K. D. Karlin, M. S. Nasir, B. I. Cohen, R. W. Cruse, S. Kaderli and A. D. Zuberbühler, J. Am. Chem. Soc., 116, 1324-1336 (1994).

(16) K.D. Karlin, A. Nanthakumar, S. Fox, N.N. Murthy, N. Ravi, B.H Huynh, R.D. Orosz and E.P. Day, J. Am. Chem. Soc. 116, 4753-4763 (1994).

(17) A. Nanthakumar, S. Fox, N.N. Murthy and K. D. Karlin, J. Am. Chem. Soc. 119, 3898-3906 (1997).

(18) S. Fox, A. Nanthakumar, M. Wikström, K. D. Karlin and N. J. Blackburn, J. Am. Chem. Soc. 118, 24-34 (1996)

(19) K. D. Karlin, S. Fox, A. Nanthakumar, N. N. Murthy, N. Wei, H. V. Obias, and C. F. Martens, Pure \& Appl. Chem., 67, 289-296 (1995).

(20) C. F. Martens, N. N. Murthy, H. V. Obias and K. D. Karlin, Chem. Commun., 629-630 (1996).

(21) P. Girsch and S. de Vries, Biochim. Biophys. Acta, 1318, 202-216 (1997). 